\title{
The Somatotropic Axis in Short Children Born Small for Gestational Age: Relation to Insulin Resistance
}

\author{
KATIE A. WOODS, MARIA VAN HELVOIRT, KEN K.L. ONG, ANGELICA MOHN, \\ JONATHAN LEVY, FRANCIS DE ZEGHER, AND DAVID B. DUNGER \\ Department of Paediatrics [K.A.W, K.K.L.O., D.B.D.], Addenbrooke's Hospital, Cambridge, UK; \\ Department of Paediatrics [M.V.H., F.D.Z.], University of Leuven, Leuven, Belgium; Clinica Pediatrica \\ [A.M.], Ospedale Polyclinico Colledell-Ara 66100, Chieti, Italy; and Diabetes Research Laboratories \\ [J.L.], Radcliffe Infirmary, Oxford, UK.
}

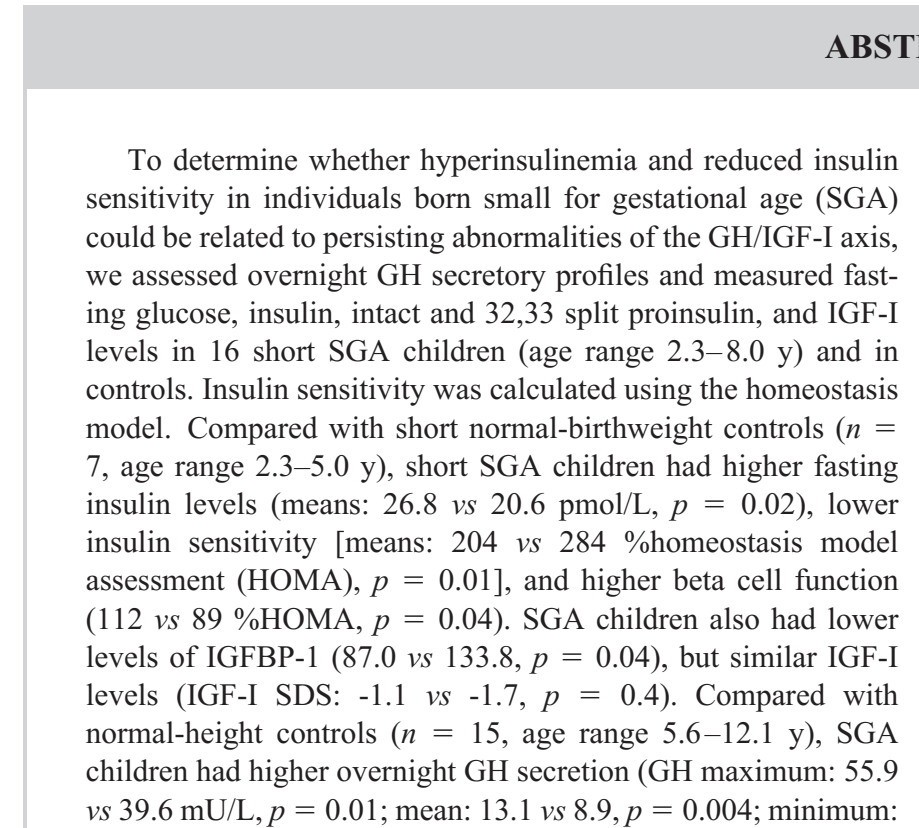

Endocrine studies in utero show that growth retarded fetuses have reduced insulin $(1,2)$ and IGF-I levels $(3-5)$, and in the neonatal period, babies born SGA have low IGF-I levels despite elevated GH secretion (6-10), a pattern characteristic of $\mathrm{GH}$ insensitivity $(11,12)$. Approximately $10 \%$ to $15 \%$ of these SGA infants remain small in childhood, as defined by height $<-2$ SDS (13-15). Failure of catch-up growth is associated with severity of intra-uterine growth retardation and persisting low IGF-I levels (9, 16-18), suggesting ongoing dysfunction of the GH/IGF-I axis (19). In contrast to their high

Received November 29, 2000; accepted July 31, 2001.

Correspondence and reprint requests to: Professor David B. Dunger, Department of Paediatrics, University of Cambridge, Addenbrooke's Hospital Box 116, Cambridge CB2 2QQ UK; e-mail: dbd25@cam.ac.uk

The authors thank Pharmacia Upjohn for their generous support in this study. M.V.H was supported by a visiting scholarship from the European Society for Paediatric Endocrinology, and F.D.Z is a Clinical Research Investigator of the Fund for Scientific Research, Flanders, Belgium.
1.2 vs $0.6, p=0.02$ ). Interestingly, among SGA children, fasting insulin levels and insulin sensitivity were significantly related to overnight GH secretion (insulin sensitivity $v s$ maximum GH: $\mathrm{r}=$ $-0.68, p=0.01$; vs $\mathrm{GH}$ pulse amplitude $\mathrm{r}=-0.71, p=0.007$ ). The only hormone level significantly related to current height velocity was $\mathrm{C}$-peptide ( $\mathrm{r}=0.75, p=0.008)$. In conclusion, elevated fasting insulin levels and reduced insulin sensitivity in short SGA children was related to elevated levels of overnight $\mathrm{GH}$ secretion. We hypothesize that resistance to the somatotropic actions of GH and IGF-I in short SGA children may contribute directly to reduced insulin sensitivity. (Pediatr Res 51: 76-80, 2002)
SDS, SD score
SGA, small for gestational age
HOMA, homeostasis model assessment
IGFBP-1, IGF binding protein-1

neonatal GH levels, older SGA children may have reduced GH secretion, although most do not develop "classic" GH deficiency $(17,19-21)$.

In addition to impaired postnatal growth, reduced size at birth has been associated with increased risk of adult diseases, including type 2 diabetes, syndrome $\mathrm{X}$, and cardiovascular disease $(22,23)$. Insulin resistance is a common feature of these conditions and has been independently associated with low birthweight both in adults (24) and children $(25,26)$, suggesting that this metabolic abnormality may be central to the link between reduced prenatal growth and adult disease.

The GH/IGF-I axis and insulin sensitivity/secretion are closely related. Sustained elevation of GH levels results in decreased insulin sensitivity at the liver and in peripheral tissues $(27,28)$. In contrast, IGF-I has insulin-like metabolic effects, particularly in muscle where IGF-I receptor density is high (29) and low IGF-I levels might reduce peripheral glucose 
uptake. In subjects with insulin deficiency and insulin resistance, such as those with malnutrition or type 1 diabetes, a GH resistant pattern of elevated GH and reduced IGF-I is often observed $(30,31)$. We postulated that insulin resistance in short SGA children might be related to persisting abnormalities of the GH/IGF-I axis. To explore this hypothesis, we examined GH secretion, IGF-I levels, and insulin secretion/sensitivity in young SGA children with postnatal growth failure.

\section{METHODS}

\section{Subjects}

Short SGA children. Subjects were selected from two centers (John Radcliffe Hospital, Oxford, UK, and Gasthuisberg University Hospital, Leuven, Belgium) according to the following criteria: birthweight and/or length $<-2$ SD for gestational age; current height SDS $<-3.0$; height velocity SDS $<0.0$; and chronological age $2-8 \mathrm{y}$. Subjects with an identified syndrome other than Silver-Russell syndrome were excluded, and no child was receiving medication for chronic disease. Sixteen children were recruited and their clinical characteristics are summarized in Table 1. Birthweight, length, current height, weight, and body mass index $\left(\mathrm{BMI} \mathrm{kg} / \mathrm{m}^{2}\right)$ were converted to age and sex-adjusted SD scores using the current UK reference (32). Height velocity was calculated as height gained over the previous $12 \mathrm{mo}(\mathrm{cm} / \mathrm{y})$ as measured in the hospitalbased Growth Clinics.

Controls. Two control groups were studied: short normalbirthweight children (height SDS $<-2$ and birthweight SDS $>-2 ; n=7$; Table 1 ) were identified from community screening records and had fasting blood samples collected; and overnight GH profiles were performed on 15 (8 male) normalstature (mean height SDS $=-0.1$, range -1.3 to 1.1 ) prepubertal children (mean age $=9.3 \mathrm{y}$, range 5.6 to 12.1 ). Protocols for $\mathrm{GH}$ profiles and $\mathrm{GH}$ assays were similar to those used in the SGA group $(33,34)$.

\section{Study Protocol}

The local ethics committees in Oxford and Leuven approved the study and informed consent was obtained from parents and children. SGA children were first admitted to hospital for the overnight GH profile. Blood for serum GH estimation was withdrawn from an indwelling venous canula at 20-minute intervals between 19.00 and $07.00 \mathrm{~h}$. Children followed their normal eating pattern during this period.
On a separate occasion, after $3 \mathrm{~d}$ of unrestricted diet and an overnight fast, at $8.30 \mathrm{~h}$ a venous blood sample was collected for measurement of glucose, insulin, C-peptide, intact proinsulin, 32,33 split proinsulin, IGF-I, IGFBP-I, IGFBP-3, and leptin.

Short normal-birthweight controls. These children were fasted from midnight and had a single blood sample at $08.30 \mathrm{~h}$ assayed for glucose, insulin, C-peptide, intact proinsulin, 32,33 split proinsulin, IGF-I, IGFBP-I, IGFBP-3, and leptin.

Normal-stature controls. These children underwent an overnight GH profile using the same protocol and assays as used in the SGA children.

\section{Assays}

Blood glucose was measured using a Y.S.I. model 2300 stat plus analyser (Yellow Springs Instruments, Ltd, Hants, UK). The intra and inter-assay coefficients of variation (CV) were $2.6 \%$ and $8.8 \%$ at $4.4 \mathrm{mmol} / \mathrm{L}$. Insulin was measured using a double antibody RIA from Diagnostic Systems Laboratories (DSL, Webster, TX, U.S.A.). Intra-assay CV was $8.3 \%$ at 33.6 pmol/L and inter-assay CV was $12.2 \%$ at $34.3 \mathrm{pmol} / \mathrm{L}$. Crossreactivity with proinsulin in this assay is approximately $40 \%$. Intact proinsulin and 32,33 split proinsulin were measured using a time resolved fluorometric assay (35); inter-assay CVs were $<10 \%$. The intact proinsulin assay shows typically $<1 \%$ cross-reaction with insulin and 32,33 split proinsulin. Crossreaction of the 32,33 split proinsulin assay with insulin was $<1 \%$ at $2500 \mathrm{pmol} / \mathrm{L}$, and there was $100 \%$ cross-reaction with intact proinsulin; therefore, to obtain a specific measure of 32,33 split proinsulin, the intact proinsulin concentration of the specimen was subtracted. C-peptide was measured using a double antibody RIA from Diagnostic Products Corporation (Glyn Rhonwy, Llanberis, UK); intra and inter-assay CVs were $3.4 \%$ and $10.0 \%$. IGF-I was measured by RIA using an established in-house method (36) following acid-acetone extraction; intra and inter-assay CV's were $6.2 \%$ and $3.5 \%$. IGFBP- 1 was measured by RIA using a solid phase second antibody separation phase; intra and inter-assay CVs were $4.0 \%$ and $5.7 \%$. IGFBP-3 was measured using a Coated-Tube immunoradiometric assay (IRMA) from distal sensory latency; intra-assay $\mathrm{CV}$ was $3.9 \%$ at $7.3 \mathrm{ng} / \mathrm{mL}$ and inter-assay $\mathrm{CV}$ was $0.6 \%$ at 8.0 $\mathrm{ng} / \mathrm{mL}$. Leptin was measured by RIA from Linco (St. Charles, MO, U.S.A.); intra and inter-assay CVs were $4.0 \%$ and $5.7 \%$ at $4.9 \mathrm{ng} / \mathrm{mL}$. GH was measured by IRMA (North East Thames Regional Immunoassay Unit, Bartholomew Close, London,

Table 1. Clinical characteristics of the short SGA and short normal birthweight children

\begin{tabular}{|c|c|c|c|c|}
\hline & \multicolumn{2}{|c|}{ Short SGA $(n=16) 9 \mathrm{M}, 7 \mathrm{~F}$} & \multicolumn{2}{|c|}{ Controls $(n=7) 5 \mathrm{M}, 2 \mathrm{~F}$} \\
\hline & Mean & Range & Mean & Range \\
\hline Age & *5.82 (M 5.4, F 6.3) & 2.3 to 8.0 & 3.64 & 2.3 to 5.0 \\
\hline Birth length SDS & $-3.6(\mathrm{M}-4.9, \mathrm{~F}-2.9)$ & -0.3 to -6.1 & NA & NA \\
\hline Height SDS & $* *-3.4(\mathrm{M}-3.6, \mathrm{~F}-3.2)$ & -5.5 to -2.8 & -2.3 & -2.7 to -2.0 \\
\hline Weight SDS & $* *-4.4(\mathrm{M}-4.5, \mathrm{~F}-4.3)$ & -7.2 to -2.6 & -2.1 & -2.7 to -0.9 \\
\hline
\end{tabular}

$\mathrm{M}$, male; F, female; NA, not available.

$* p<0.05 . * * p<0.005$. 
UK) using the international reference standard 80/505; intraassay CVs were 8.0, 2.0, and 3.4\% at 2.9, 14.3 and $69.4 \mathrm{mU} / \mathrm{L}$ and inter-assay CVs were $9.4,7.7$, and $10.5 \%$ at $3.5,15.2$ and $77.4 \mathrm{mU} / \mathrm{L}$.

\section{Calculations}

Overnight GH profiles were analyzed using the Pulsar program. Peak selection criteria appropriate for our own assay conditions and data set were established. The minimum, mean and maximum GH levels, area under the curve above baseline (AUCb), total number of peaks, and mean peak amplitude were derived.

Insulin sensitivity and beta cell function were calculated from fasting glucose and insulin values using HOMA, version 2, a structural computer model of the glucose/insulin feedback system (37). Insulin sensitivity and beta cell function are expressed in relation to "standard adults," accorded the value $100 \%$.

Sex- and age-standardized SD scores for IGF-I levels were calculated by comparison with normal reference data (38).

\section{Statistical analysis}

Analyses were carried out using the computer statistical package SPSS (Version 7.5) for windows. Mean values were compared using $t$ test or one-way ANOVA. The relationships between continuously distributed parameters were explored using linear regression.

\section{RESULTS}

Fasting Hormone Levels. Short SGA children had higher fasting insulin levels $(p=0.02)$ compared with short normalbirthweight children, with no differences in glucose and Cpeptide levels (Table 2). HOMA modeling of fasting insulin and glucose levels indicated that short SGA children had lower insulin sensitivity $(p=0.01)$, but higher beta-cell function ( $p$ $=0.04$ ) reflecting compensatory hyperinsulinemia.

IGF-I levels in short SGA children were on average one SD lower than published population means (37), but these levels were not lower compared with short normal-birthweight con-

Table 2. Fasting hormone levels in short SGA and short normal-birthweight children

\begin{tabular}{lccc}
\hline & $\begin{array}{c}\text { SGA group } \\
(n=16)\end{array}$ & $\begin{array}{c}\text { Controls } \\
(n=7)\end{array}$ & $\begin{array}{c}p \text { value } \\
(t \text { test })\end{array}$ \\
\hline Glucose (mmol/l) & $3.8(0.5)$ & $3.9(0.6)$ & $\mathrm{NS}$ \\
Insulin (pmol/1) & $26.8(6.3)$ & $20.6(8.1)$ & 0.02 \\
Insulin sensitivity (HOMA \%) & $204(61)$ & $284(67)$ & 0.01 \\
Beta cell function (HOMA \%) & $112(33)$ & $89(15)$ & 0.04 \\
Proinsulin (pmol/1) & $2.0(1.3)$ & $1.8(0.7)$ & $\mathrm{NS}$ \\
32, 33 split proinsulin (pmol/1) & $5.9(6.1)$ & $3.5(1.0)$ & $\mathrm{NS}$ \\
Insulin/proinsulin ratio & $5.0(4.0)$ & $10.0(4.3)$ & 0.02 \\
C-peptide (nmol/1) & $0.19(0.13)$ & $0.23(0.07)$ & $\mathrm{NS}$ \\
Leptin (ng/ml) & $2.6(0.7)$ & $3.9(1.1)$ & 0.004 \\
IGF-I SDS & $-1.1(1.1)$ & $-1.7(0.6)$ & $\mathrm{NS}$ \\
IGFBP-1 (ng/ml) & $87.0(87.2)$ & $133.8(127.0)$ & 0.04 \\
IGFBP-3 (ng/ml) & $3.1(1.2)$ & $2.3(0.3)$ & $\mathrm{NS}(0.07)$ \\
\hline
\end{tabular}

Values are mean (SD).

NS, no significant difference $(p>0.05)$. trols $(p=0.2)$. Short SGA children also had lower IGFBP-1 levels $(p=0.04)$, and lower leptin levels $(p=0.004)$ than controls, reflecting their lower BMI.

Overnight GH levels. Of the 16 short SGA children, 13 had overnight GH profile completed, and all these had a maximum overnight $\mathrm{GH}$ level of at least $30 \mathrm{mU} / \mathrm{L}$, ruling out $\mathrm{GH}$ insufficiency. Indeed, when compared with normal-stature controls, short SGA children had higher maximum $(p=0.01)$, mean $(p=0.004)$, minimum $(p=0.004)$, and $\operatorname{AUCb}(p=$ 0.02 ) overnight $\mathrm{GH}$ levels and also an increased GH pulse frequency ( $p=0.02$; Table 3$)$.

GH/IGF-I axis and insulin sensitivity. Among short SGA children, fasting insulin levels and insulin sensitivity were significantly related to maximum overnight $\mathrm{GH}$ levels (fasting insulin level: $\mathrm{r}=0.65, p=0.02$; HOMA insulin sensitivity: $\mathrm{r}$ $=-0.68, p=0.01$; Fig. 1). HOMA insulin sensitivity was even more closely related to the maximum GH pulse amplitude $(\mathrm{r}=-0.71, p=0.007)$, but was unrelated to minimum $\mathrm{GH}$ levels $(\mathrm{r}=0.0, p=1.0)$ or $\mathrm{GH}$ pulse frequency $(\mathrm{r}=-0.15$, $p=0.6)$.

Maximum overnight GH levels were also inversely related to leptin ( $\mathrm{r}=-0.56, p=0.05)$, but not to BMI, IGF-I, IGFBP-1, or IGFBP-3 levels. Among SGA children, the only hormone or growth factor which correlated significantly with current height velocity was C-peptide ( $\mathrm{r}=0.75, p=0.008$, Table 4).

\section{DISCUSSION}

The aim of this study was to examine the relationship between the GH/IGF-I axis and insulin sensitivity/secretion in young short SGA children. Our short SGA children were younger (mean age $=5.8 \mathrm{y}$ ) and shorter (mean height SDS $=$ -3.4) than those in whom insulin sensitivity has previously been reported (26). Despite being thinner and shorter than the short normal-birthweight controls, these short SGA children had higher fasting insulin levels. HOMA assessment of insulin sensitivity takes into account the effect of variation in fasting blood glucose levels on the insulin levels; although this model has only been validated in adult populations, our findings that short SGA children have reduced insulin sensitivity and increased beta cell function are entirely consistent with results from a similar population using the modified minimal model assessment (26). Furthermore, the elevated fasting insulin levels and reduced insulin sensitivity in these short SGA children

Table 3. Parameters of overnight GH secretion in SGA children and normal-stature controls

\begin{tabular}{lccc}
\hline \multicolumn{1}{c}{ GH $(\mathrm{mU} / \mathrm{l})$} & $\begin{array}{c}\text { SGA group } \\
(n=13)\end{array}$ & $\begin{array}{c}\text { Control group } \\
(n=15)\end{array}$ & $\begin{array}{c}p \text { value } \\
(t \text { test })\end{array}$ \\
\hline Maximum & $55.9(30.4-80.5)$ & $39.6(15.6-75.9)$ & 0.01 \\
Mean & $13.1(7.2-19.1)$ & $8.9(3.7-18.5)$ & 0.004 \\
Minimum & $1.2(<0.4-2.1)$ & $0.6(0.5-1.3)$ & 0.004 \\
No. of pulses & $5.4(3-7)$ & $4.3(3-8)$ & 0.02 \\
Area under curve & $115.8(62.0-171.1)$ & $84.1(28.7-165.8)$ & 0.02 \\
Pulse amplitude & $25.2(17.4-36.7)$ & $20.6(9.1-40.8)$ & NS $(0.12)$ \\
\hline
\end{tabular}

Values are mean (range).

NS, not significant. 


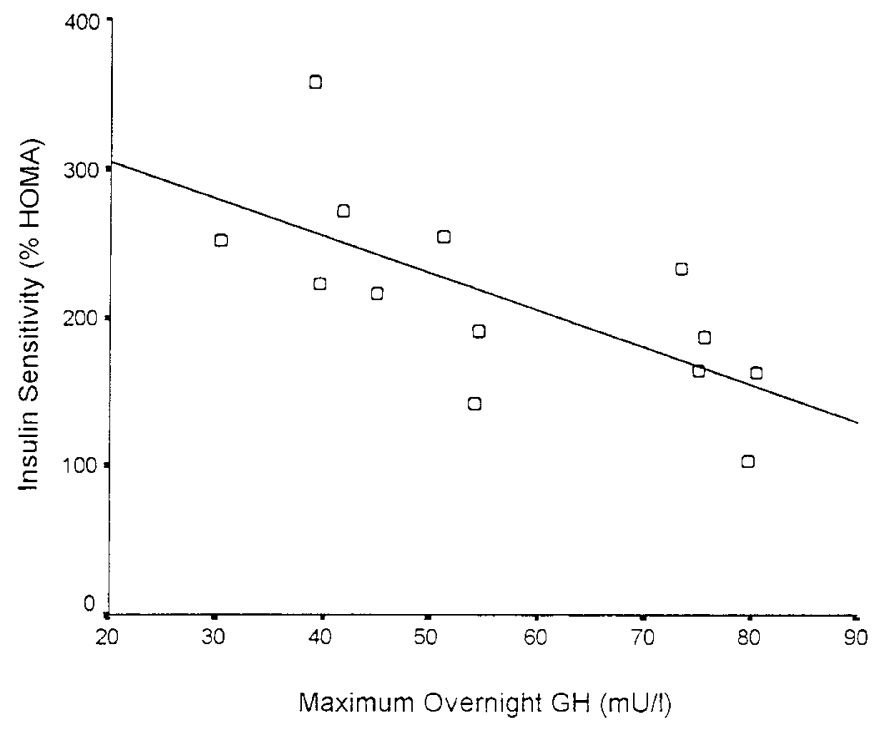

Figure 1. Scattergraph of insulin sensitivity (HOMA) against maximum overnight GH level in short SGA children $(\mathrm{r}=-0.68, p=0.01, n=13)$.

Table 4. Correlation coefficients between current height velocity and hormone levels in short SGA children

\begin{tabular}{lrc}
\hline & $\mathrm{r}$ & $p$ value \\
\hline Glucose & 0.12 & $\mathrm{NS}(0.7)$ \\
Insulin & -0.11 & $\mathrm{NS}(0.7)$ \\
C-peptide & 0.75 & 0.008 \\
Proinsulin & 0.21 & $\mathrm{NS}(0.5)$ \\
IGF-I & 0.13 & $\mathrm{NS}(0.6)$ \\
IGFBP-1 & -0.54 & $\mathrm{NS}(0.08)$ \\
IGFBP-3 & 0.37 & $\mathrm{NS}(0.3)$ \\
GH maximum & 0.06 & $\mathrm{NS}(0.9)$ \\
GH mean & 0.06 & $\mathrm{NS}(0.9)$ \\
Insulin sensitivity & 0.20 & $\mathrm{NS}(0.5)$ \\
Beta-cell function & -0.15 & $\mathrm{NS}(0.6)$ \\
\hline
\end{tabular}

NS, not significant.

was significantly related to their levels of overnight GH secretion.

Despite their severe short stature, all parameters of overnight GH secretion (maximum, mean, minimum, AUCb, and pulse frequency) were higher in short SGA children compared with normal-stature prepubertal controls, and also higher compared with published normative data in prepubertal populations (17, 19, 39). Previous studies in short SGA children have reported reduced spontaneous GH secretion compared with controls, although most are not GH deficient (17-19). The different findings in our short SGA children may relate to their younger age; young SGA children have been noted to have a distinct pattern of GH secretion with high baseline levels and increased pulse frequency (19).

IGF-I levels in our short SGA children were on average one SD lower than the population reference (38), which is consistent with other studies $(9,16-18)$. However, despite being shorter and thinner, the IGF-I levels in our short SGA children were not lower compared with short normal-birthweight controls. It has been suggested that short SGA children may have a degree of IGF-I resistance as higher basal and GH-induced IGF-I levels are required to achieve a growth velocity similar to that of other children (40). Relative IGF-I resistance at the pituitary could contribute to the elevated GH secretion seen in our short SGA children, and would also be compatible with the observation that supra-physiologic GH doses are required to significantly improve final height prognosis in short SGA children (41-43). Thus, short SGA children may appear to have a shift in the set point of their GH/IGF-I axis.

In addition to its effects on IGF-I production, GH has important metabolic effects that are in part independent of IGF-I action. These "direct" GH effects include enhancement of protein synthesis, lipolysis, and reduction in body fat mass (44). Thus, children with GH deficiency or GH receptor deficiency tend to be obese $(45,46)$. However, as in our study, short SGA children are often thin $(17,19,41)$, suggesting that they remain sensitive to the metabolic effects of GH. The elevated pattern of GH secretion seen in our short SGA children is similar to that observed during fasting or malnutrition (47) and could lead to increased lipolysis and the development of insulin resistance.

GH also has well-documented insulin antagonistic effects $(27,28)$. GH reduces glucose uptake in peripheral tissues such as muscle through an effect on postreceptor insulin signaling $(28,48)$. GH may also reduce insulin sensitivity by increasing lipolysis and circulating free-fatty acid levels (49). Thus, defects in the GH/IGF-I axis in short SGA children resulting in elevated GH secretion may directly contribute to their increased fasting insulin levels and reduced insulin sensitivity.

In the presence of reduced insulin sensitivity, the ability of the beta-cell to produce compensatory hyperinsulinemia are important in maintaining glucose homeostasis, as clearly shown by recent animal knockout studies of the genes encoding insulin receptor substrate 1 and $2(50,51)$. In our study, C-peptide, a marker of integrated insulin secretion, was the only hormone level related to current height velocity. Thus, the ability to increase insulin secretion in compensation for insulin resistance may be an important determinant of both glucose homeostasis and continuing growth in short SGA children.

In contrast, the role of the GH/IGF-I axis in regulating growth in short SGA children is less obvious from our data. The lack of significant association between GH and IGF-I levels may be expected in this small sample; however, neither hormone was related to growth velocity. Our short SGA children had lower IGFBP-1 levels than controls, and it could be postulated that the compensatory hyperinsulinemia in response to peripheral insulin resistance might lower IGFBP-1 levels and thereby improve IGF-I bioavailability. This could be a mechanism whereby growth is maintained in the presence of relative GH and IGF-I resistance. The improvement in IGF-I bioavailability, if sustained, could eventually lead to suppression of GH secretion as seen in older SGA children (17-19).

In conclusion, these data suggest that the GH/IGF-I axis may be impaired in young short SGA children and this may contribute to their reduced insulin sensitivity. These observations indicate the need to carefully monitor the use of high dose $\mathrm{GH}$ therapy in SGA children, which could influence any association between reduced prenatal growth, small size at birth, and the subsequent risk of adulthood disease. 
Acknowledgments. The authors thank Professor CN Hales for measuring the intact and 32,33 split proinsulin levels and Karin Van Wesen $\mathrm{RN}$ for logistic assistance in performing the study.

\section{REFERENCES}

1. Economides DL, Nicolaides KH, Campbell S 1991 Metabolic and endocrine findings in appropriate and small for gestational age fetuses. J Perinat Med 19:97-105

2. Economides DL, Proudler A, Nicolaides KH 1989 Plasma insulin in appropriate- and small-for-gestational-age fetuses. Am J Obstet Gynecol 160:1091-1094

3. Lassarre C, Hardouin S, Daffos F, Forestier F, Frankenne F, Binoux M 1991 Serum insulin-like growth factors and insulin-like growth factor binding proteins in the human fetus. Relationships with growth in normal subjects and in subjects with intrauterine growth retardation. Pediatr Res 29:219-225

4. Giudice LC, de Zegher F, Gargosky SE, Dsupin BA, de las Fuentes L, Crystal RA, Hintz RL, Rosenfeld RG 1995 Insulin-like growth factors and their binding proteins in the term and preterm human fetus and neonate with normal and extremes of intrauterine growth. J Clin Endocrinol Metab 80:1548-1555

5. Leger J, Oury JF, Noel M, Baron S, Benali K, Blot P, Czernichow P 1996 Growth factors and intrauterine growth retardation. I. Serum growth hormone, insulin-like growth factor (IGF)-I, IGF-II, and IGF binding protein 3 levels in normally grown and growth- retarded human fetuses during the second half of gestation. Pediatr Res 40:94-100

6. de Zegher F, Kimpen J, Raus J, Vanderschueren Lodeweyckx M 1990 Hypersomatotropism in the dysmature infant at term and preterm birth. Biol Neonate 58:188-191

7. Langford K, Blum W, Nicolaides K, Jones J, McGregor A, Miell J 1994 The pathophysiology of the insulin-like growth factor axis in fetal growth failure: a basis for programming by undernutrition? Eur J Clin Invest 24:851-856

8. Varvarigou A, Vagenakis AG, Makri M, Beratis NG 1994 Growth hormone, insulinlike growth factor-I and prolactin in small for gestational age neonates. Biol Neonate 1994:65:94-102

9. Leger J, Noel M, Limal JM, Czernichow P 1995 Growth factors and intrauterine growth retardation. II-Serum growth hormone, insulin-like growth factor (IGF)-I, and IGF-binding protein 3 levels in children with intrauterine growth retardation as compared with normal controls: prospective study from birth to two years of age. Pediatr Res 40:101-107

10. Ogilvy Stuart AL, Hands SJ, Adcock CJ, Holly JM, Matthews DR, Mohamed Ali V, Yudkin JS, Wilkinson AR, Dunger DB 1998 Insulin, insulin-like growth factor I (IGF-I), IGF-binding protein-1, growth hormone, and feeding in the newborn. J Clin Endocrinol Metab 83:3550-3557

11. Savage MO, Woods KA 1996 The investigation of growth hormone insensitivity. Clin Endocrinol (Oxf) 45:257-260

12. Cance-Rouzaud A, Laborie S, Bieth E, Tricoire J, Rolland M, Grandjean H, Rochiccioli P, Tauber M 1998 Growth hormone, insulin-like growth factor-I and insulinlike growth factor binding protein-3 are regulated differently in small-for-gestationalage and appropriate-for-gestational-age neonates. Biol Neonate 73:347-355

13. Fitzhardinge PM, Inwood S 1989 Long-term growth in small-for-date children. Clin Endocrinol (Oxf) 349:27-33

14. Karlberg J, Albertsson Wikland K 1995 Growth in full-term small-for-gestational-age infants: from birth to final height. Pediatr Res 38:733-739

15. Leger J, Limoni C, Czernichow P 1997 Prediction of the outcome of growth at 2 years of age in neonates with intra-uterine growth retardation. Early Hum Dev 48:211-223

16. Thieriot-Prevost G, Boccara JF, Francoual C, Badoual J, Job JC 1988 Serum insulin-like growth factor 1 and serum growth-promoting activity during the first postnatal year in infants with intrauterine growth retardation. Pediatr Res 24:380-383

17. de Waal WJ, Hokken-Koelega AC, Stijnen T, de Muinck Keizer-Schrama SM, Drop SL 1994 Endogenous and stimulated GH secretion, urinary GH excretion, and plasma IGF-I and IGF-II levels in prepubertal children with short stature after intrauterine growth retardation. Clin Endocrinol (Oxf) 41:621-630

18. Boguszewski M, Jansson C, Rosberg S, Albertsson Wikland K 1996 Changes in serum insulin-like growth factor I (IGF-I) and IGF- binding protein-3 levels during growth hormone treatment in prepubertal short children born small for gestational age. J Clin Endocrinol Metab 81:3902-3908

19. Boguszewski M, Rosberg S, Albertsson Wikland K 1995 Spontaneous 24-hour growth hormone profiles in prepubertal small for gestational age children. J Clin Endocrinol Metab 80:2599-2606

20. Rochiccioli P, Tauber M, Moisan V, Pienkowski C 1989 Investigation of growth hormone secretion in patients with intrauterine growth retardation. Acta Paediatr Scand Suppl 349:42-46

21. Stanhope R, Ackland F, Hamill G, Clayton J, Jones J, Preece MA 1989 Physiological growth hormone secretion and response to growth hormone treatment in children with short stature and intrauterine growth retardation. Acta Paediatr Scand Suppl 349:47-52

22. Barker DJ, Hales CN, Fall CH, Osmond C, Phipps K, Clark PM 1993 Type 2 (non-insulin-dependent) diabetes mellitus, hypertension and hyperlipidaemia (syndrome X): relation to reduced fetal growth. Diabetologia 36:62-67

23. Barker DJ, Gluckman PD, Godfrey KM, Harding JE, Owens JA, Robinson JS 1993 Fetal nutrition and cardiovascular disease in adult life. Lancet 341:938-941

24. Phillips DI, Barker DJ, Hales CN, Hirst S, Osmond C 1994 Thinness at birth and insulin resistance in adult life. Diabetologia 37:150-154
25. Yajnik CS, Fall CH, Vaidya U, Pandit AN, Bavdekar A, Bhat DS, Osmond C, Hales CN, Barker DJ 1995 Fetal growth and glucose and insulin metabolism in four-yearold Indian children. Diabet Med 12:330-336

26. Hofman PL, Cutfield WS, Robinson EM, Bergman RN, Menon RK, Sperling MA, Gluckman PD 1997 Insulin resistance in short children with intrauterine growth retardation. J Clin Endocrinol Metab 82:402-406

27. Bratusch Marrain PR, Smith D, DeFronzo RA 1982 The effect of growth hormone on glucose metabolism and insulin secretion in man. J Clin Endocrinol Metab 55:973982

28. Moller N, Butler PC, Antsiferov MA, Alberti KG 1989 Effects of growth hormone on insulin sensitivity and forearm metabolism in normal man. Diabetologia 32:105-110

29. Laager R, Ninnis R, Keller U 1993 Comparison of the effects of recombinant human insulin-like growth factor-I and insulin on glucose and leucine kinetics in humans. J Clin Invest 92:1903-1909

30. Soliman AT, Hassan AE, Aref MK, Hintz RL, Rosenfeld RG, Rogol AD 1986 Serum insulin-like growth factors I and II concentrations and growth hormone and insulin responses to arginine infusion in children with protein-energy malnutrition before and after nutritional rehabilitation. Pediatr Res 20:1122-1130

31. Clayton KL, Holly JM, Carlsson LM, Jones J, Cheetham TD, Taylor AM, Dunger DB 1994 Loss of the normal relationships between growth hormone, growth hormonebinding protein and insulin-like growth factor-I in adolescents with insulin-dependent diabetes mellitus. Clin Endocrinol (Oxf) 41:517-524

32. Freeman JV, Cole TJ, Chinn S, Jones PRM, White EM, Preece MA 1995 Cross sectional stature and weight reference curves for the UK. Arch Dis Child 73:17-24

33. Edge JA, Dunger DB, Matthews DR, Gilbert JP, Smith CP 1990 Increased overnight growth hormone concentrations in diabetic compared with normal adolescents. J Clin Endocrinol Metab 1990:71:1356-1362

34. Matyka KA, Dunger DB 1999 Counterregulation during spontaneous nocturnal hypoglycaemia in prepubertal children with type 1 diabetes. Diabetes Care 22:11441150

35. Sobey WJ, Beer SF, Carrington CA, Clark PM, Frank BH, Gray IP, Luzio SD, Owens DR, Schneider AE, Siddle K 1989 Sensitive and specific two-site radioimmunometric assays for human insulin, proinsulin, 65-66 and 32,33 split proinsulin. Biochem J 260:535-541

36. Helle SI, Anker GB, Meadows KA, Holly JM, Lonning PE 1998 Alterations in the insulin-like growth factor system during the menstrual cycle in normal women. Maturitas 28:259-265

37. Matthews DR, Hosker JP, Rudenski AS, Naylor BA, Treacher DF, Turner RC 1985 Homeostasis model assessment: insulin resistance and beta-cell function from fasting plasma glucose and insulin concentrations in man. Diabetologia 28:412-419

38. Blum WF 1992 Insulin-like growth factors and their binding proteins. In: Ranke MB (ed) Functional Endocrinologic Diagnosis in Children and Adolescents. JJ Verlag, Mannheim, pp 102-117

39. Ackland FM, Stanhope R, Eyre C, Hamill G, Jones J, Preece MA 1988 Physiological growth hormone secretion in children with short stature and intra-uterine growth retardation. Horm Res 30:241-245

40. Chatelain PG, Niccolino M, Claris O, Salle B, Chaussain JL 1998 Multiple hormone resistance in short children born with intrauterine growth retardation? Horm Res 49:20-22

41. de Zegher F, Maes M, Gargosky SE, Heinrichs C, Du Caju MV, Thiry G 1996 High-dose growth hormone treatment of short children born small for gestational age. J Clin Endocrinol Metab 81:1887-1892

42. de Zegher F, Francios I, van Helvoirt M, van den Berghe G 1997 Small as a fetus and short as a child: from endogenous to exogenous growth hormone. J Clin Endocrinol Metab 7:2021-2026

43. Stanhope R, Preece MA, Hamill G 1991 Does growth hormone treatment improve final height attainment of children with intrauterine growth retardation? Arch Dis Child 66:1180-1183

44. Berneis K, Keller U 1996 Metabolic actions of growth hormone: direct and indirect. In: Ross RJM, Savage MO (eds) Growth Hormone Resistant States. Ballière-Tindall, London, pp 337-352

45. Brook CJD 1973 Effect of human growth hormone treatment on adipose tissue in children. Arch Dis Child 48:725-728

46. Woods KA, Savage MO 1996 Laron syndrome: typical and atypical forms. In: Ross RJM, Savage MO (eds) Growth Hormone Resistance. Ballière Tindall, London, pp 371-388

47. Scacchi M, Pincelli AI, Caumo A, Tomasi P, Delitala G, Baldi G, Cavagnini F 1997 Spontaneous nocturnal growth hormone secretion in anorexia nervosa. J Clin Endocrinol Metab 82:3225-3229

48. Rosenfeld RG, Wilson DM, Dollar LA, Bennett A, Hintz RL 1982 Both human pituitary growth hormone and recombinant DNA-derived human growth hormone cause insulin resistance at a postreceptor site. J Clin Endocrinol Metab 54:1033-1038

49. Piatti PM, Monti LD, Caumo A, Conti M, Magni F, Galli-Kienle M, Fochesato E, Pizzini A, Baldi L, Valsecchi G, Pontiroli AE 1999 Mediation of the hepatic effects of growth hormone by its lipolytic activity. J Clin Endocrinol Metab 84:1658-1663

50. Tamemoto H, Kadowaki T, Tobe K, Yagi T, Sakura H, Hayakawa T, Terauchi Y, Ueki K, Kaburagi Y, Satoh S 1994 Insulin resistance and growth retardation in mice lacking insulin receptor substrate-1. Nature 372:182-186

51. Terauchi Y, Iwamoto K, Tamemoto H, Komeda K, Ishii C, Kanazawa Y, Asanuma N, Aizawa T, Akanuma Y, Yasuda K, Kodama T, Tobe K, Yazaki Y, Kadowaki T 1997 Development of non-insulin-dependent diabetes mellitus in the double knockout mice with disruption of insulin receptor substrate-1 and beta cell glucokinase genes. Genetic reconstitution of diabetes as a polygenic disease. J Clin Invest 99:861-866 